\title{
IAEA Cooperative Research Project Status Report
}

\author{
James C. Kinsey
}

The INL is a

U.S. Department of Energy

National Laboratory

operated by

Battelle Energy Alliance

August 2016
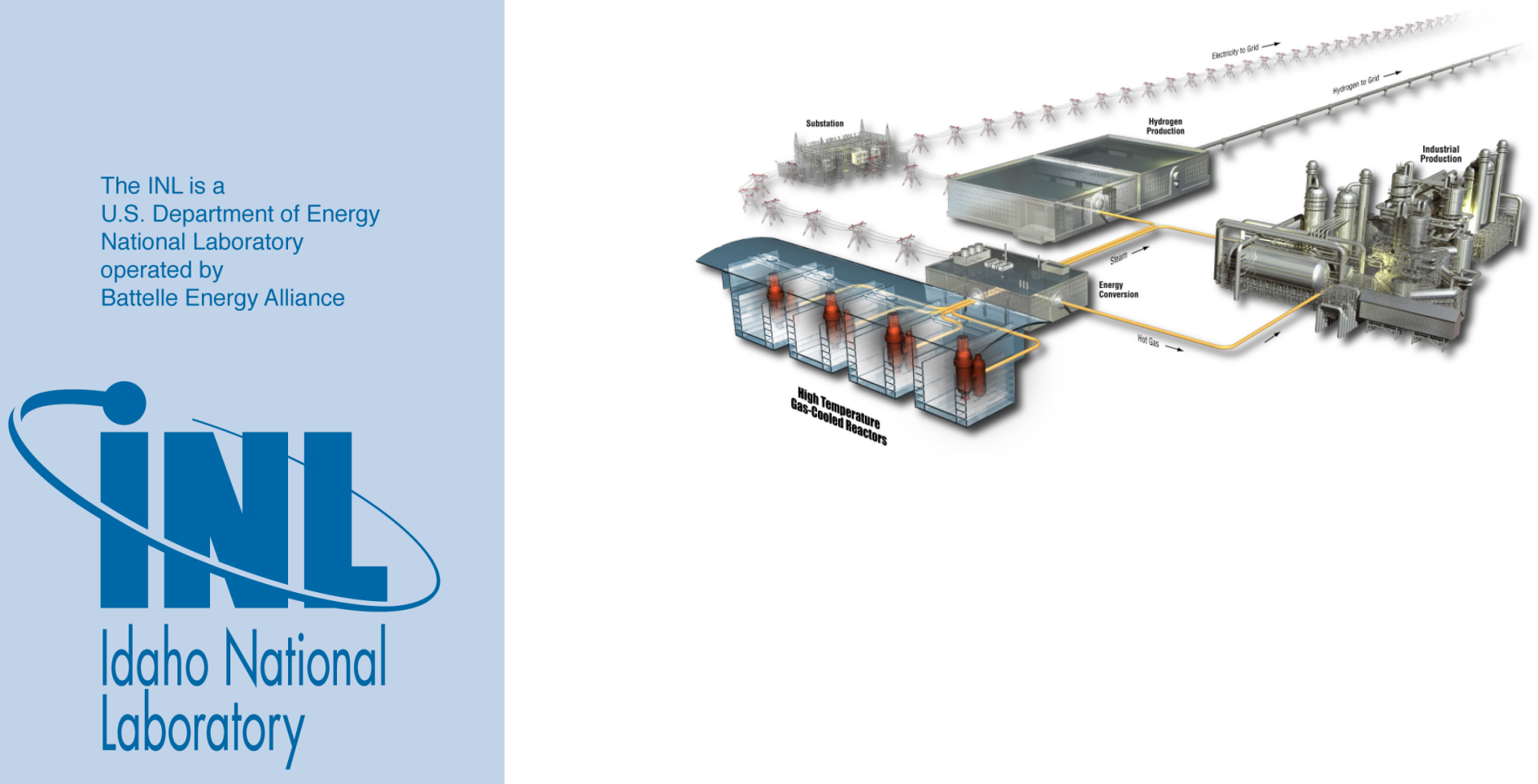


\section{DISCLAIMER}

This information was prepared as an account of work sponsored by an agency of the U.S. Government. Neither the U.S. Government nor any agency thereof, nor any of their employees, makes any warranty, expressed or implied, or assumes any legal liability or responsibility for the accuracy, completeness, or usefulness, of any information, apparatus, product, or process disclosed, or represents that its use would not infringe privately owned rights. References herein to any specific commercial product, process, or service by trade name, trade mark, manufacturer, or otherwise, does not necessarily constitute or imply its endorsement, recommendation, or favoring by the U.S. Government or any agency thereof. The views and opinions of authors expressed herein do not necessarily state or reflect those of the U.S. Government or any agency thereof. 
INL/EXT-16-39750

Revision 0

\title{
IAEA Cooperative Research Project Status Report
}

\author{
James C. Kinsey
}

August 2016

\begin{abstract}
Idaho National Laboratory
INL ART Program

Idaho Falls, Idaho 83415
\end{abstract}

http://www.inl.gov

\author{
Prepared for the \\ U.S. Department of Energy \\ Office of Nuclear Energy \\ Under DOE Idaho Operations Office \\ Contract DE-AC07-05ID14517
}



INL ART Program

\title{
IAEA Cooperative Research Project Status Report
}

\author{
INL/EXT-16-39750
}

Revision 0

August 2016

Approved by:

Mare SP2la for fimkinsey

Jim C. Kinsey

INL ART Licensing Director

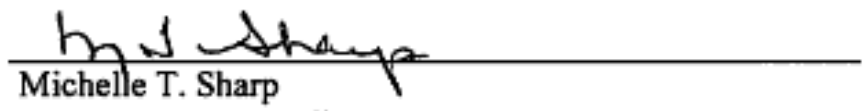

INL ART TDO Quality Assurance

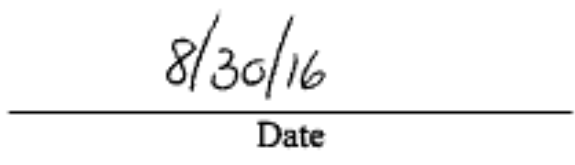

$8 / 30 / 16$ Date 



\section{Summary}

This report provides an end-of-year summary that reflects the progress and status of United States (U.S.) activities supporting the International Atomic Energy Agency (IAEA) Cooperative Research Project (CRP) effort to develop Modular High Temperature Reactor (HTGR) Safety Design Criteria. These U.S. activities are being managed by the Idaho National Laboratory (INL) on behalf of the U.S. Department of Energy (DOE), and it is noted that this summary reflects progress during the second year of this planned three year activity. This status summary addresses Level 3 milestone M3AT-16IN2001104 in work package AT-16IN200110.

The U.S. developed material and documented the content in a report titled "Inputs to IAEA on Safety Design Criteria for Modular High Temperature Gas-Cooled Reactors" (INL/EXT-16-38812, Revision 0). The report was provided to the IAEA CRP members as the primary current-year U.S. input to this multi-year effort and includes:

- A discussion of the inherent or intrinsic safety characteristics of the modular HTGR.

- A summary of relevant past work in the U.S. related to HTGR safety for both the pebble bed and the prismatic design types, including available feedback from the U.S. Nuclear Regulatory Commission (NRC) regarding the safety design approach and event evaluation process proposed for the Next Generation Nuclear Plant (NGNP).

- A summary of a proposed process flow from top level requirements to the safety design approach, identification of the spectrum of licensing basis events, and the establishment of required safety functions that support the safety design approach to meet the offsite dose requirements.

- Development and discussion of a clear delineation between the treatment of design basis events and beyond design basis events in terms of the evaluation methods and the associated acceptance criteria.

Planned U.S. contributions to this CRP effort in FY2017 include (1) development of a summary description of the modular HTGR's approach to defense in depth, and (2) development of a summary discussion of how the implementation of the proposed safety design process addresses the key lessons learned from the events at Fukushima. 


\section{CONTENTS}

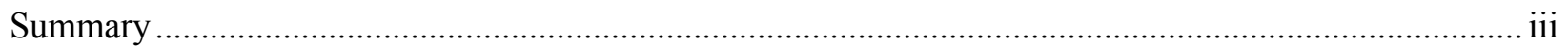

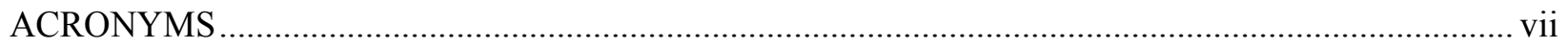

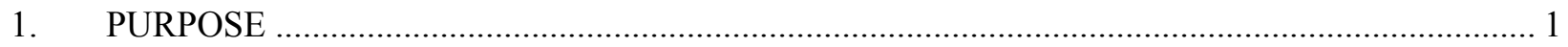

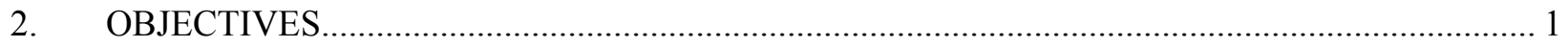

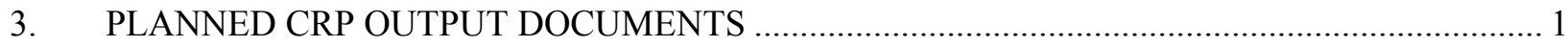

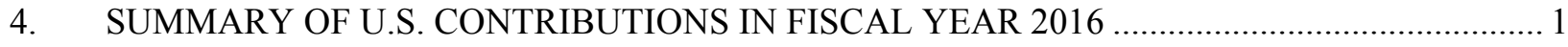

5. PLANNED U.S. CONTRIBUTIONS FOR FISCAL YEAR 2017 ............................................ 3

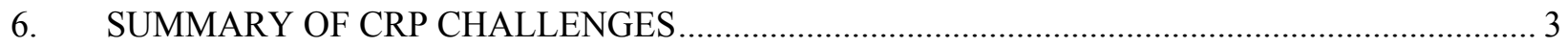

\section{FIGURES}

Figure 1. Flow diagram for development of modular HTGR safety design criteria.................................. 2 


\section{ACRONYMS}

CRP Cooperative Research Project

DOE U.S. Department of Energy

FY fiscal year

HTGR high temperature gas-cooled reactor

IAEA International Atomic Energy Agency

INL Idaho National Laboratory

LWR light water reactor

NGNP Next Generation Nuclear Plant

NRC Nuclear Regulatory Commission

RCM Research Coordination Meeting

U.S. United States 


\section{IAEA Cooperative Research Project Status Report 1. PURPOSE}

This report provides an end-of-year summary that reflects the progress and status of United States (U.S.) activities supporting the International Atomic Energy Agency (IAEA) Cooperative Research Project (CRP) effort to develop Modular High Temperature Reactor Safety Design Criteria. These U.S. activities are being managed by the Idaho National Laboratory (INL) on behalf of the U.S. Department of Energy (DOE), and it is noted that this summary reflects progress during the second year of this planned three year activity.

This status summary addresses Level 3 milestone M3AT-16IN2001104 in work package AT-16IN200110.

\section{OBJECTIVES}

Modular High Temperature Gas-Cooled Reactors (modular HTGRs) have a number of intrinsic and inherent properties or characteristics that preclude or minimize the potential for large radionuclide release from multi-reactor plant sites to the public. The development and implementation of comprehensive Safety Design Criteria would provide a high level of assurance that modular HTGRs are consistently designed, constructed, and operated in a manner that takes advantage of these intrinsic properties, while also avoiding unintended compromises in plant safety.

It is expected that the safety design criteria being developed within this CRP effort will refer to IAEA's previously developed Light Water Reactor (LWR) safety standards (e.g., IAEA SSR-2/1) as one input, while also considering the insights and inputs of member states with experience in modular HTGR research and technology development. The criteria developed through this CRP can then be used during the further development of existing and planned HTGRs worldwide to assure that an acceptably broad spectrum of design and beyond design basis events are addressed in the designs. The events from the Fukushima-Daiichi accident are being considered during the establishment of the process for developing these criteria.

\section{PLANNED CRP OUTPUT DOCUMENTS}

The results of the CRP will be documented in an IAEA TECDOC format. Those safety design criteria outputs, and the process flow steps that are being developed to establish them, will be considered for inclusion in the future separate activities of the development of IAEA Safety Standards for HTGRs with the cooperation of the department of Nuclear Safety and Security at IAEA.

\section{SUMMARY OF U.S. CONTRIBUTIONS IN FISCAL YEAR 2016}

The U.S. developed the following material through this work package during Fiscal Year 2016 (FY16), and documented the content in a report titled "Inputs to IAEA on Safety Design Criteria for Modular High Temperature Gas-Cooled Reactors" (INL/EXT-16-38812, Revision 0). The report was provided to the IAEA CRP members as the primary current-year U.S. input to this multi-year effort in accordance with previously established IAEA Research Agreement No. 18737, and includes:

- A discussion of the inherent or intrinsic safety characteristics of the modular HTGR. The discussion includes a summary of the characteristics of the fuel, moderator materials, and reactor configuration supporting this safety case, such as the control of heat generation and the use of passive features for heat removal. 
- A summary of relevant past work in the U.S. related to HTGR safety for both the pebble bed and the prismatic design types, including available feedback from the U.S. Nuclear Regulatory Commission (NRC) regarding the safety design approach and event evaluation process proposed for the Next Generation Nuclear Plant (NGNP).

- A summary of a proposed process flow from top level requirements to the safety design approach, identification of the spectrum of licensing basis events, and the establishment of required safety functions that support the safety design approach to meet the offsite dose requirements (see Figure 1).

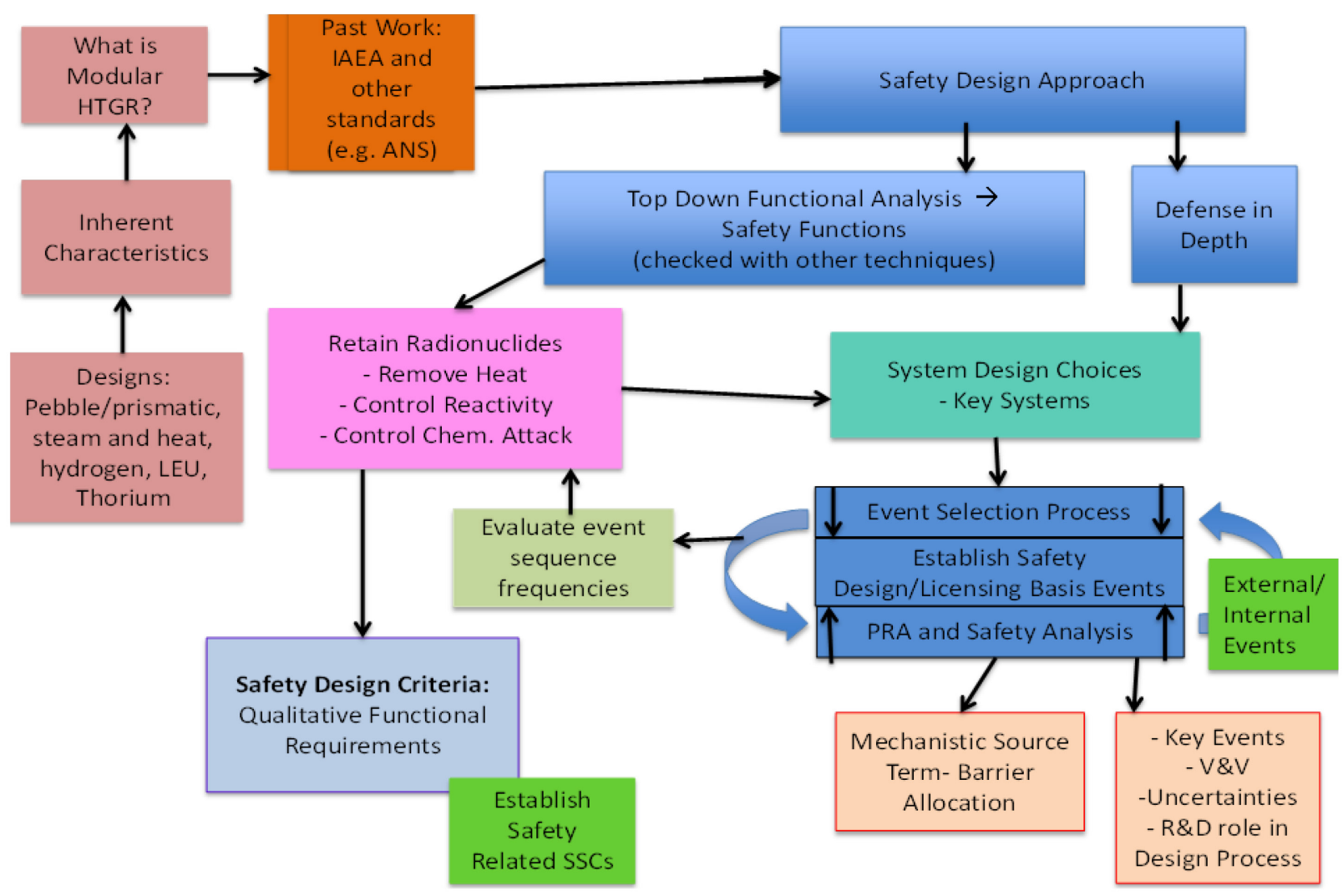

Figure 1. Flow diagram for development of modular HTGR safety design criteria.

- Development and discussion of a clear delineation between the treatment of design basis events and beyond design basis events in terms of the evaluation methods and the associated acceptance criteria.

The U.S. members of this CRP team also reviewed draft inputs and deliverables provided by other member states, and participated in a Research Coordination Meeting (RCM) held at IAEA headquarters in June 2016. Member States and technology development representatives attending the RCM included Japan, Indonesia, Kazakhstan, United Kingdom, China, Germany, Korea, FZJ Research Center (Juelich, Germany), and Ukraine.

The purpose of the RCM, which is the second of three planned, was to review member country contributions and progress since the initiation of the CRP on Modular High Temperature Reactor Safety Design Criteria (I31026). The existing safety design criteria, licensing experience, reference designs, and definitions from the different member states on which the new proposed safety criteria will be based were reviewed and further refined, with a number of remaining action items being established.

A primary focus of this second RCM was to review and discuss the key attributes regarding a risk-informed and performance-based approach to safety design criteria development (“Approach 1") 
versus a more prescriptive and deterministic method (“Approach 2") that starts from historical LWR-based criteria, such as IAEA Safety Standard SSR-2/1. It is noted that the U.S. proposals regarding "Approach 1" have been developed directly from the process flow utilized by the DOE's NGNP project, including insights from the related dialogue and reviews provided by the NRC.

\section{PLANNED U.S. CONTRIBUTIONS FOR FISCAL YEAR 2017}

Planned U.S. contributions to this CRP effort in FY2017 include the following deliverables:

- Development of a summary description of the modular HTGR's approach to defense in depth through the incorporation of multiple independent barriers to radionuclide release. The summary will include a discussion of available U.S. regulator's assessment of this approach to defense in depth.

- Development of a summary discussion of how the implementation of the proposed safety design process addresses the key lessons learned from the events at Fukushima (e.g., events impacting more than one reactor on a multi-reactor site, interdependence of radionuclide release barriers, reliance on active systems and operator actions, adequate cooling of spent fuel, etc.).

In addition to these specific U.S. deliverables, the CRP team will be implementing previously committed and newly identified tasks during this next year of the project, with a plan for the next RCM to be held in June 2017. Actions and activities are expected to be more extensive in this coming year, since the primary output deliverable (IAEA TECDOC) is expected to be largely developed and in draft form for focused review at the 2017 meeting.

\section{SUMMARY OF CRP CHALLENGES}

The primary challenge remaining for the CRP is to establish an agreed upon process flow that allows for the integration or "blending" of the risk-informed performance based "Approach 1" with the largely LWR-based and prescriptive "Approach 2". This integration is further challenged by the differing regulatory structures and regulator expectations in the various Member States, and the LWR-based precedents established within existing IAEA Safety Standards. 